Volume 2 Issue 2, September 2018: pp. 460-483. Copyright (c) 2018 HOLREV. Faculty of Law, Halu Oleo University, Kendari, Southeast Sulawesi, Indonesia. ISSN: 2548-1762 | e-ISSN: 2548-1754. Open Access at: http://ojs.uho.ac.id/index.php/holrev/

Halu Oleo Law Review is licensed under a Creative Commons Attribution 4.0 International License, which permits unrestricted use, distribution, and reproduction in any medium, provided the original work is properly cited.

\title{
Pengiriman Paket Menggunakan Grab Express Beserta dengan Bentuk Pertanggungjawabannya
}

\author{
Package Delivery Using Grab Express and its Responsibility
}

\author{
Dina Kusuma Ratih \\ Fakultas Hukum Universitas Airlangga \\ E-mail: diraakusuma@gmail.com \\ Hilda Yunita Sabrie \\ Fakultas Hukum Universitas Airlangga \\ E-mail: hilda.sabrie@fh.unair.ac.id
}

\begin{abstract}
As stipulated in Government Regulation No. 74 of 2014 on Road Transport (PP No. 74/2014, motorcycles can be used as a means of transporting goods with a record must meet technical requirements. In addition, the use of motorcycles is also considered more effective and efficient for the delivery of goods because it can reach the destination more quickly.Along with the growth and development of technology, finally led to a new innovation in the form of merging technology with the procurement of transportation services. The innovation of the vehicle booking service through applications on smart phones. The emergence of this innovation in Indonesia is quite liked by the community because it is more effective and efficient Looking at the demand of the community is quite a lot, this makes a promising business opportunities. There are so many emerging application service providers of transportation companies Go-Jek Indonesia, Uber Indonesia and Grab Indonesia. with this online transport is a form of responsibility in terms of transporting. So it is necessary to know further so that online transport users can be more secure and comfortable when using services offered primarily for Grab Express applications. This article takes Grab Indonesia sample as research material. This research is a legal research that is normative meaning all that is studied is based on legislation. In addition, the approach used in this study is a conseptual approach and a research approach.
\end{abstract}

Keyword: Online Transportation; Grab Indonesia; Grab Express; Transportation; Responsible

Abstrak: Seperti yang diatur dalam Peraturan Pemerintah No. 74 Tahun 2014 Tentang Angkutan Jalan (PP No. 74/2014, sepeda motor dapat digunakan sebagai alat angkut barang dengan catatan harus memenuhi syarat teknis. Selain itu penggunaan sepeda motor juga dirasa lebih efektif dan efisien untuk pengiriman 
barang karena dapat menjangkau tempat tujuan dengan lebih cepat. Seiring dengan pertumbuhan dan perkembangan teknologi, akhirnya memunculkan suatu inovasi baru berupa penggabungan teknologi dengan pengadaan jasa pengangkutan. Inovasi tersebut berupa layanan pemesanan kendaraan melalui aplikasi pada ponsel pintar. Kemunculan inovasi ini di Indonesia cukup disukai oleh masyarakat karena lebih efektif dan efisien. Melihat permintaan masyarakat yang cukup banyak, hal ini membuat suatu peluang bisnis yang cukup menjanjikan. Sehingga sampai saat ini banyak bermunculan perusahaan aplikasi penyedia layanan transportasi yakni GoJek Indonesia, Uber Indonesia dan Grab Indonesia. Permasalahan yang timbul dengan adanya transportasi online ini adalah bentuk tanggung jawabnya dalam hal melakukan pengangkutan. Sehingga perlu kiranya diketahui lebih jauh agar pengguna transportasi online dapat lebih aman dan nyaman ketika menggunakan jasa yang ditawarkan terutama untuk aplikasi Grab Express. Artikel ini mengambil sampel Grab Indonesia sebagai bahan penelitian. Penelitian ini merupakan penelitian hukum yang bersifat normative artinya semua yang dikaji adalah berdasar peraturan perundang-undangan. Selain itu pendekatan yang di gunakan dalam penelitian ini adalah conseptual approach dan research approach.

Kata kunci: Transportasi Online; Grab Indonesia; Grab Express; Pengangkutan; Tanggung Jawab.

\section{PENDAHULUAN}

Fokus pembahasan dalam penelitian ini adalah perusahaan Grab Indonesia. Grab Indonesia merupakan perusahaan penyedia layanan pemesanan kendaraan di Indonesia. Hadir di Indonesia sejak pertengahan 2014 lalu, Grab Indonesia telah mengukir sejarah tersendiri di dunia transportasi berbasis teknologi. Sampai saat ini layanan tersebut cukup mendapat apresiasi sehingga mantap mengembangkan bisnisnya. ${ }^{1}$ Berasal dari Malaysia dan berbasis di Singapura, Grab telah tersebar di negara-negara kawasan Asia seperti Singapura, Malaysia, Thailand, Vietnam, Filipina dan Indonesia. Tujuan dari Grab Indonesia adalah untuk merevolusi layanan pengangkutan dan memberikan keamanan dan kenyamanan bagi pengguna kendaraan di Indonesia.

Berawal dari aplikasi penyedia taksi, pemesanan kendaraan mobil serta juga sepeda motor pada awal kemunculannya, saat ini Grab Indonesia telah melebarkan jenis layanannya. Tetap pada jalur penyedia aplikasi layanan pengangkutan, kini terdapat beberapa layanan baru pada Grab Indonesia yakni Grab Food, Grab Express, Hitch Bike,

1 Nita Novita, 'Profil Singkat Grab', Grab Indonesia, http://nitanovitasr.blogspot.co.id/2016/10/profilsingkat-grab.html, diakses pada tanggal 25 Oktober 2017. 
Hitch Car, Parcel dan Rental. Berikut adalah penjelasan terkait layanan yang tersedia pada aplikasi Grab Indonesia yang telah diakses dari website Grab Indonesia: ${ }^{2}$

1. Grab Taxi. Merupakan layanan angkutan orang menggunakan taksi konvensional. Grab Taxi memberi akses para konsumen untuk menemukan taksi terdekat dengan aman pada aplikasi Grab. Kendaraan yang akan didapat berupa taksi konvensional resmi di setiap kota yang pengemudinya telah terdaftar dan terseleksi dan telah mengikuti pelatihan keselamatan;

2. Grab Car. Merupakan layanan angkutan orang menggunakan mobil pribadi. Penyewaan kendaraan pribadi beserta dengan sopirnya dengan kebebasan untuk memilih kendaraan yang nyaman dan selamat. Model kendaraan yang digunakan adalah mobil pribadi dengan jenis family car;

3. Grab Bike. Merupakan layanan angkutan orang dengan menggunakan sepeda motor sebagai sarana utama pengangkutan. Pengemudinya, telah terdaftar dan berlisensi dengan atribut sehingga dapat menjamin keamanan konsumen;

4. Grab Express. Merupakan layanan kurir ekspres atau pengantaran barang yang dilakukan berbasis aplikasi. Barang yang diantar dapat berupa paket dan juga dokumen. Pengiriman menggunakan sepeda motor sebagai moda pengangkutan;

5. Grab Food. Merupakan layanan pengantaran makanan yang dapat dipesan oleh konsumen melalui aplikasi dan makanan yang diantar tetap terjaga dan aman. Konsumen hanya memilih restoran yang diinginkan dan makanan yang dipesan, lalu driver Grab akan mengantar pesanannya;

6. Grab Hitch Bike. Merupakan produk layanan tebengan dengan sepeda motor dari Grab Indonesia dengan harga terjangkau sambil mengurangi polusi. Grab Hitch akan mencari pengemudi dan dicocokkan dengan calon penumpang dengan arah/rute yang sama. Pembayarannya sendiri untuk layanan ini hanya separuh harga dari layanan Grab Bike;

7. Grab Hitch Car. Layanan ini hampir sama dengan Grab Hitch Bike, hanya saja pengangkutan menggunakan mobil sebagai moda pengangkutannya. Pengemudi Grab Hitch bukanlah pengemudi komersial. Mereka adalah orangorang biasa yang memiliki rute sama seperti kamu. Dengan memberi tebengan, pengemudi Grab Hitch dapat menghemat sebagian biaya;

8. Grab Rental. Grab Rental adalah layanan rental online yang memudahkan pelanggan untuk melakukan pemesanan mobil selama minimal 6 jam (termasuk pengemudi dan bahan bakar) dari lokasi penjemputan menuju beberapa lokasi sesuai dengan coverage area yang telah ditentukan oleh Grab;

9. Grab Parcel. Merupakan layanan kurir yang lebih kompleks dari Grab Express dengan maksimum pengiriman yang lebih besar namun belum menjangkau ke seluruh kota di Indonesia.

Pada layanan yang telah disebutkan di atas oleh Grab Indonesia melalui aplikasinya, alat pengangkutan yang digunakan adalah taksi konvensional, mobil pribadi serta sepeda motor pribadi. Taksi konvensional juga menjadi salah satu sarana alat angkut yang

2 Grab Indonesia, 'Layanan', Grab Indonesia, http://www.grab.com/id/ diakses pada tanggal 25 Oktober 2017. 
digunakan pada Grab Indonesia, karena telah bermitra dengan perusahaan taksi konvensional. Perusahaan taksi konvensional tersebut adalah Orenz Taksi. Untuk taksi konvensional ini, dikemudikan oleh driver yang bekerja pada perusahaan taksi tersebut. Namun untuk mobil pribadi dan sepeda motor pribadi yang digunakan untuk melakukan layanan pengangkutan, dikemudikan oleh driver yang terdaftar sebagai mitra pada Grab Indonesia. Sehingga driver yang terdaftar masing-masing menggunakan kendaraan pribadinya.

Penggunaan sepeda motor sebagai moda pengangkutan pada Grab Indonesia dapat dikatakan lebih dominan dari moda angkutan yang lain. Hal ini dikarenakan kegiatan pengangkutan pada Grab Indonesia menggunakan sepeda motor lebih banyak, karena mitra Grab Indonesia pada layanan dengan menggunakan sepeda motor lebih besar daripada yang menggunakan mobil maupun taksi. Layanan Grab Indonesia yang menggunakan sepeda motor sebagai moda pengangkutannya antara lain, Grab Bike, Grab Food, Grab Hitch Bike dan Grab Express.

Grab Express adalah layanan kurir secara kilat menggunakan sepeda motor sebagai moda pengangkutannya dan dibatasi suatu ruang lingkup wilayah kecil. Layanan ini sangat menarik, sebab pengiriman barang dari tempat asal dan penerimaan barang di lokasi tujuan dapat dilakukan pada hari yang sama. Barang yang dapat dikirimkan pun beragam. Salah Satu kelebihannya adalah setiap barang yang dikirimkan menggunakan Grab Express akan secara langsung terasuransikan. Hal yang menjadi pembeda antara Grab Express dengan ekspedisi konvensional adalah proses penyerahan barang. Pada perusahaan ekspedisi konvensional seperti Ti-Ki, J\&T dan Si-Cepat misalnya, pada penyerahan barang, pengirim wajib mendatangi kantor pengiriman terlebih dahulu. Setelah itu pengirim mendaftarkan barangnya dengan membayar sejumlah biaya yang nantinya akan timbul sebuah dokumen pengiriman. Setelah terbit dokumen pengiriman maka pengirim akan menyerahkan barang dan tinggal menunggu barang tersebut sampai ditangan penerima. Kelemahan dari ekspedisi konvensional salah satunya adalah pengirim tidak dapat melakukan pelacakan lokasi sampai dimana barang yang dikirim.

Berbeda dengan ekspedisi konvensional, proses penyerahan barang dan pelacakan lokasi barang dapat dilakukan dengan efisien. Pada penyerahan barang, driver akan mendatangi lokasi penjemputan barang yang telah ditulis dalam konfirmasi pemesanan melalui aplikasi. Setelah tiba di lokasi penjemputan barang, pengirim menyerahkan barang dengan disertai biaya atas jasa pengiriman. Kemudian driver akan mengirimkan paket 
tersebut kepada penerima yang dituju dengan aman, cepat dan selamat. Pengirim juga dapat dengan mudah melacak dan memantau pengiriman barang tersebut melalui aplikasi seperti pada gambar berikut ini:
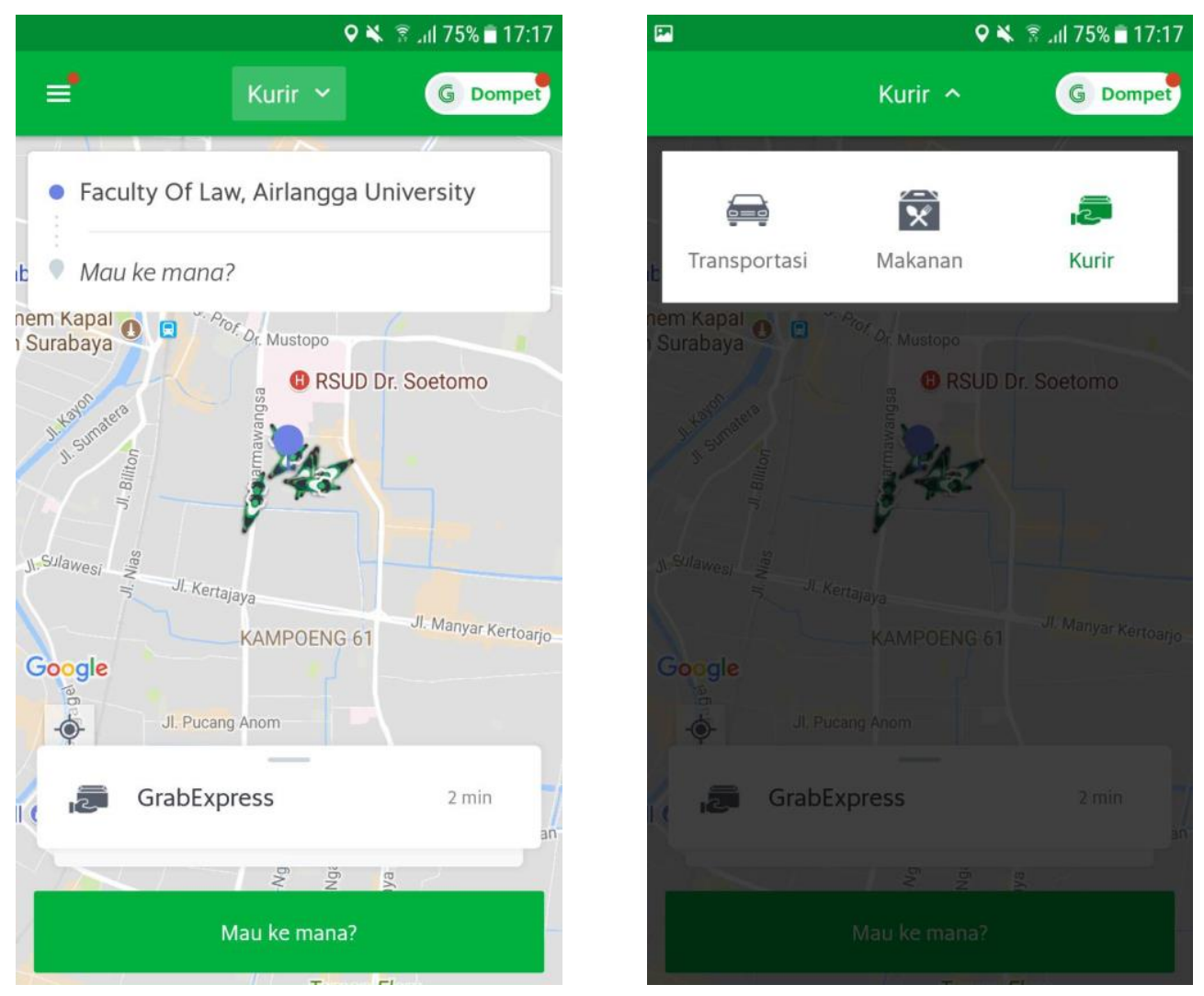

Pada proses pengiriman barang menggunakan Grab Express seperti yang sudah diulas di atas, tentunya melibatkan beberapa pihak. Seperti yang dijelaskan di atas, pihak yang dapat diidentifikasi adalah pengirim barang, penerima barang, driver dan Grab Indonesia. Para pihak tersebut tentunya memiliki peran, tugas serta hak dan kewajiban masing-masing, yang dapat dijelaskan sebagai berikut:

1. Grab Indonesia. Pada pelaksanaan pengiriman barang Grab Express, Grab Indonesia berperan sebagai ekspeditor. Hal ini dikarenakan karena Grab Indonesia yang menyediakan layanan namun tidak serta merta mengangkut barang pengiriman itu sendiri. Grab Indonesia mencarikan calon pengirim dan/atau penerima barang seorang driver dengan metode acak lewat aplikasi. Grab Indonesia juga menjamin para konsumen pengguna layanan Grab Express akan mendapat pengirim yang memiliki itikad baik melakukan pengiriman dengan alat angkut berupa sepeda motor yang sesuai degan ketentuan yang 
berlaku serta memastikan bahwa driver akan mengantarkan barang dengan aman dan selamat sesuai waktu tiba.

2. Driver, bertugas untuk mengantarkan paket. Peran dari driver Grab Express bila dikaitkan dengan pihak dalam pengangkutan adalah sebagai pengangkut. Pada Pasal 91 KUHD, kewajiban utama dari pengangkut adalah untuk menyelenggarakan pengangkutan dari suatu tempat ke tempat tujuannya. Sehingga driver Grab Express berkewajiban menyelenggarakan pengangkutan pengiriman barang dan juga berkewajiban untuk menjaga keselamatan barang yang diangkutnya hingga sampai ke tempat tujuan sesuai dengan perjanjian pengangkutan.

3. Pengirim Barang. Kedua pihak ini bertindak selaku konsumen layanan Grab Express. Sebagai pemakai jasa angkutan, pengirim berkewajiban untung membayar biaya kirim sebagai wujud pertukaran prestasi dari penyelenggaraan angkutan itu sendiri. Kewajiban ini baru timbul apabila diperjanjikan terlebih dahulu, sebab menurut Pasal 491 KUHD, kewajiban membayar uang angkutan ada pada penerima setelah barang-barang diterimanya. Apabila pada proses pengiriman terjadi kehilangan atau kerusakan, maka pengirim berhak menuntut ganti rugi.

\section{METODE PENELITIAN}

Penelitian ini merupakan penelitian hukum yang bersifat normatif artinya semua yang dikaji adalah berdasar peraturan perundang-undangan. Selain itu pendekatan yang di gunakan dalam penelitian ini adalah pendekatan perundang-undangan (statute approach) dan pendekatan konseptual (conseptual approach). Pendekatan perundang-undangan (statute approach) dilakukan dengan menelaah semua undang-undang dan regulasi yang bersangkut paut dengan isu hukum yang sudah diteliti. ${ }^{3}$ Pendekatan konseptual (conseptual approach) beranjak dari pandangan-pandangan dan doktrin-doktrin yang berkembang di dalam ilmu hukum. ${ }^{4}$ Sehingga menemukan dan melahirkan pengertian hukum, konsep hukum dan/atau asas hukum terkait dengan isu hukum yang sedang diteliti dan dijadikan tambahan pertimbangan dalam memecahkan isu hukum yang ada.

Peter Mahmud Marzuki, Penelitian Hukum, Jakarta: Kencana Prenadamedia Group, 2005, hlm. 133.

Ibid, hlm. 135. 


\section{ANALISIS DAN PEMBAHASAN}

\section{Mekanisme Pengiriman Barang Menggunakan Grab Express}

Proses penyelenggaraan pengangkutan menggunakan layanan Grab Express adalah berada di darat sebab dilakukan menggunakan sepeda motor sebagai moda pengangkutannya. Pengirimannya juga dilakukan terbatas hanya dalam kota saja. Misalnya untuk pengiriman dalam kota Surabaya, Grab Express hanya dapat mengantarkan paket di daerah sekitar kota Surabaya saja. Hal ini sejalan dengan tujuan dari Grab Express sendiri yakni sebagai layanan kurir instan. Namun, meskipun pengiriman yang dilakukan dengan menggunakan Grab Express hanya terbatas pada suatu ruang lingkup wilayah saja. Sehingga kemungkinan terjadinya risiko kerusakan barang pada saat pengiriman tidak dapat dihindari begitu saja. Pelaksanaan pengangkutan barang melalui jalur darat merupakan salah satu penyelenggaraan pengangkutan yang memiliki risiko tinggi. Hal ini disebabkan oleh beberapa kendala yang dialami oleh penyelenggara pengangkutan barang melalui jalur darat. Faktor-faktor yang kemungkinan dihadapi dalam proses pengangkutan menggunakan jalur darat yang dapat menimbulkan risiko adalah sebagai berikut:

1. Faktor alam seperti cuaca yang buruk atau hujan. Dalam keadaan hujan maka jarak pandang dari pengemudi sangat terbatas dan sangat rawan terjadi kecelakaan, tidak jarang proses pengangkutan itu dihentikan dengan tujuan untuk menjaga keselamatan barang. Upaya yang dapat dilakukan oleh driver adalah menghentikan kegiatan pengiriman barang untuk sementara waktu sehingga dapat mencegah terjadinya risiko kecelakaan yang berakibat pada kerusakan barang dan keterlambatan pengiriman;

2. Faktor kondisi lingkungan jalanan yang rusak dan tidak memadai sehingga menyebabkan barang rusak. Keadaan jalan raya yang rusak dapat menjadi faktor rusaknya barang yang diantar. Sebab pada saat driver melintasi jalanan tersebut, terdapat kemungkinan terjadi guncangan yang memungkinkan membuat barang tersebut rusak;

3. Kecelakaan lalu lintas, hal ini bisa terjadi karena kondisi dari kelalaian pengemudi itu sendiri dan dari pengemudi lain. Kemungkinan terjadinya kecelakaan lalu lintas yang dapat dialami oleh driver dapat menjadi salah satu faktor penyebab kerusakan barang yang dikirim; 
4. Kurang siapnya kondisi armada yang digunakan sebagai alat pengangkut, seperti ban atau rem yang sudah aus atau tipis, lampu depan atau belakang yang mati atau tidak menyala yang dapat menyebabkan terjadinya kecelakaan sehingga menimbulkan keterlambatan ataupun kerusakan barang paket;

5. Kurang bagus atau sempurnanya pembungkusan barang atau paket yang berakibat pada kerusakan barang paket.

Menindaklanjuti adanya beberapa faktor yang dapat menyebabkan risiko kerusakan pada barang saat proses penyelenggaraan pengiriman berlangsung, maka upaya yang dapat ditempuh adalah sebagai berikut:

1. Demi keselamatan driver dan barang yang dikirim, untuk menghindari faktor cuaca yang buruk ataupun hujan, upaya yang dapat dilakukan oleh driver adalah menghentikan kegiatan pengiriman barang untuk sementara waktu sehingga dapat mencegah terjadinya risiko kecelakaan yang berakibat pada kerusakan barang dan keterlambatan pengiriman.

2. Terkait dengan faktor jalanan yang rusak dan tidak memadai untuk di lewati, driver Grab Express harus lebih berhati hati dalam melajukan kendaraannya. Upaya lain yang dapat diambil adalah dengan menggunakan akses jalan lain yang keadaannya baik dan dapat dilewati sehingga pengiriman barang dapat berjalan aman dan selamat sampai tempat tujuan.

3. Menghindari faktor yang ketiga yakni kecelakaan yang disebabkan oleh driver itu sendiri. Upaya dari Grab Indonesia adalah telah melakukan pelatihan khusus bagi para driver Grab Express dalam proses pengiriman barang agar tetap aman dan selamat pada saat pengiriman barang. Pada website resminya, Grab Indonesia telah menjelaskan bahwa setiap driver pada Grab Express dibedakan dengan driver biasa pada Grab Bike. Para driver Grab Express telah mendapat pelatihan khusus untuk mengantarkan barang.

4. Demi meminimalisasi adanya kecelakaan, para driver harus memastikan bahwa armada yang digunakan dalam kondisi baik. Kondisi ban, rem dan juga lampu pada sepeda motor juga dapat mempengaruhi keselamatan dalam pengiriman barang.

5. Driver wajib memastikan bahwa barang yang dikirim sudah dibungkus dengan baik oleh pengirim. Demi menghindari adanya rusak dan/atau cacat barang pada saat pengiriman, driver dapat meminta pada pengirim untuk melakukan 
pembungkusan sempurna pada barang. Sehingga dalam hal tersebut dapat memudahkan pengiriman barang sehingga aman dan selamat sampai tujuan.

Meskipun telah dilakukan upaya pencegahan terhadap faktor yang dapat membuat barang tersebut tidak aman, akan selalu ada celah terhadap kerugian yang dialami pengirim dan/atau penerima selaku konsumen. Kerugian yang dialami oleh konsumen akibat pengiriman yang kurang hati-hati dan aman akan mengakibatkan barang tidak selamat. Tentunya hal ini dapat menimbulkan tuntutan pengirim kepada Grab Indonesia karena tidak menyelenggarakan proses pengangkutan dengan aman dan selamat. Sebab pada saat driver Grab Express telah menerima barang dari pengirim, maka pada saat itu driver Grab Express bertanggung jawab untuk menyelenggarakan pengangkutan untuk dikirim ke tempat tujuan dengan selamat.

Artinya pihak Grab Indonesia yang diwakili oleh driver Grab Express bertanggungjawab mulai sejak diterimanya barang hingga saat barang tersebut diserahkan ditangan penerima. Apabila dalam pengangkutan barang tersebut berjalan tidak aman dan selamat, maka hal ini juga menjadi tanggung jawab pengangkut. Dimana dalam hal ini pengangkut adalah Grab Indonesia yang diwakili oleh driver Grab Express.

Menurut panduan resmi penggunaan layanan Grab Express yang dapat diakses melalui situs resmi Grab Indonesia, di dalamnya mengatur terkait beberapa hal penting dalam pengiriman, yakni sebagai berikut:

1. Pengiriman dengan motor menggunakan tas kanvas

Seperti pada proses pengiriman paket secara konvensional, Grab Express juga menerapkan penggunaan tas kanvas sebagai tempat menyimpan objek pengiriman. Tujuan utama dengan digunakannya tas kanvas ini adalah agar barang yang dikirim dapat tiba di tempat tujuan dengan aman dan selamat. Adapun apabila tidak menggunakan tas kanvas, driver diwajibkan untuk mengikat barang dengan tali pengait motor. Hal ini sesuai dengan kewajiban pengangkut sebagaimana yang telah banyak dijelaskan bahwa berkewajiban untuk memastikan barang disimpan dan dikirim ke tempat tujuan dengan kondisi aman dan selamat. 


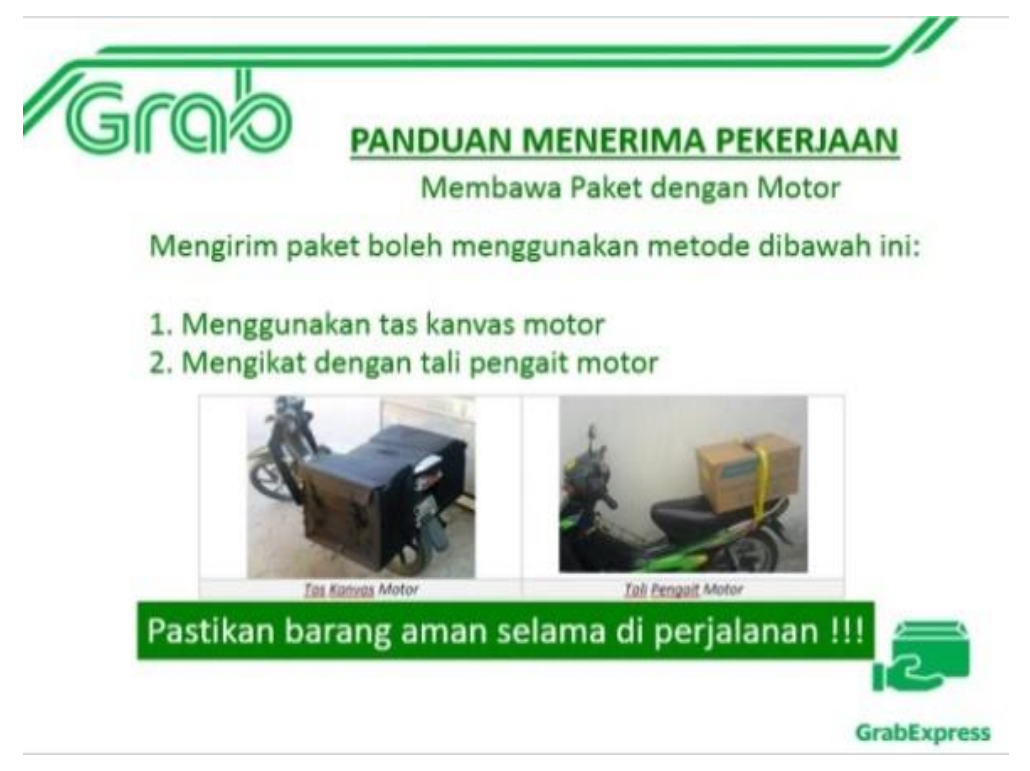

2. Jenis barang yang dapat dikirimkan dengan Grab Express

Berbeda dengan pengiriman paket konvensional yang memperbolehkan konsumen untuk mengirimkan barang apa saja selama tidak melanggar ketentuan hukum, Grab Express memberi batasan terkait barang apa saja yang dapat dikirim. Pada dasarnya Grab Express digunakan untuk melakukan pengiriman barang kilat dalam satu area yang meliputi dokumen dan barang. Pada pengiriman barang sendiri ada beberapa jenis barang yang dapat dikirimkan menggunakan Grab Express yaitu paket dengan ukuran sedang, karangan bunga, jas hujan, makanan kering yang terbungkus rapi, barang belanjaan dan juga baju. Grab Indonesia juga memiliki jenis barang yang disarankan untuk tidak dikirimkan dengan menggunakan layanan ini yaitu hewan hidup, perhiasan, senjata tajam, uang, surat berharga, narkotika dan barang-barang yang dilarang oleh hukum.

Grab Express tidak menerima pengiriman barang pecah-belah yang tidak dikemas dengan baik, makanan maupun minuman yang membutuhkan pendingin ataupun penanganan khusus, minuman beralkohol, obat-obatan, perhiasan, uang tunai ataupun benda lain yang dilarang oleh ketentuan undang-undang yang berlaku di Republik Indonesia. ${ }^{5}$ Ketentuan dalam penyelenggaraan Grab Express yang telah diatur pada situs resmi Grab Indonesia, driver memiliki hak untuk membuka dan memeriksa paket barang

5 Dikutip dari situs resmi Grab Indonesia, http://www.grab.com/id/pada tanggal 25 Oktober 2017. 
tanpa adanya pemberitahuan sebelumnya kepada konsumen. Sehingga paket yang mungkin berisi barang yang dilarang oleh ketentuan pengiriman dan dengan ini memiliki hak untuk menolak penerimaan dan pengiriman paket barang apa pun yang mana dalam pendapatnya tidak dapat dikirimkan dengan aman atau tidak melanggar hukum. ${ }^{6}$

3. Ukuran barang yang dapat dikirim

Meskipun pada poin sebelumnya mengatur tentang jenis barang yang dapat dikirim dengan layanan Grab Express, namun pengiriman tersebut tetap harus memperhatikan besarnya ukuran barang. Dalam praktiknya Grab Indonesia memiliki ketentuan bahwa paket yang dikirimkan berbobot tidak lebih dari lima kilogram atau maksimal berat paket lima kilogram. Selain itu ketentuan ukuran pada paket yang dikirim adalah dengan dimensi ukuran panjang maksimal 25 sentimeter, lebar maksimal 32 sentimeter dan tinggi maksimal 12 sentimeter.

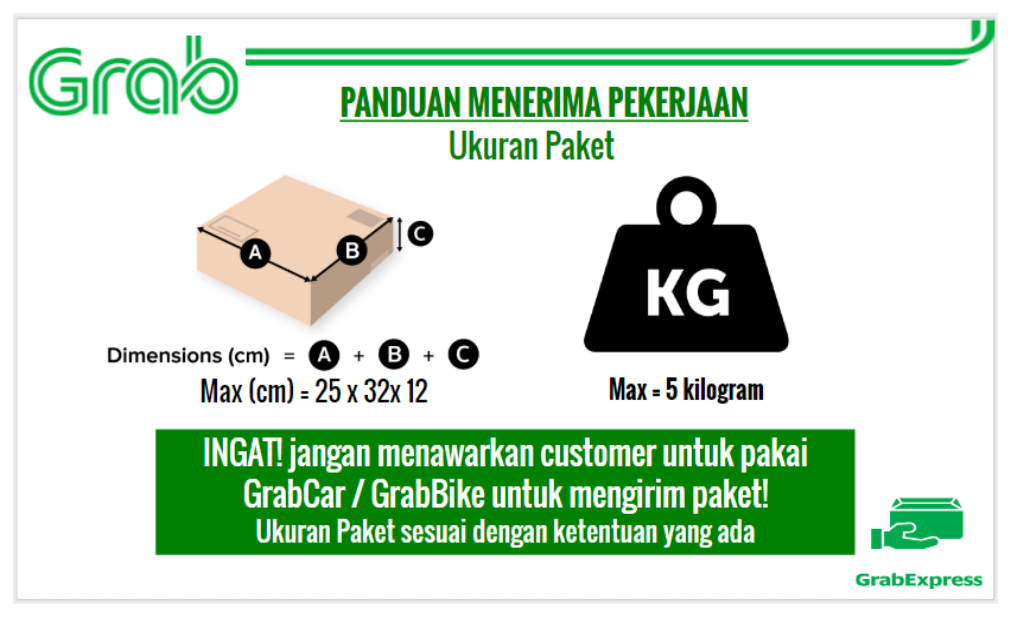

Pemberlakuan pembatasan ukuran paket oleh Grab Indonesia yang dikirim sejalan dengan ketentuan hukum terkait penggunaan sepeda motor sebagai moda pengangkutan barang. Sebelumnya telah dibahas bahwa menurut Pasal 10 ayat 4 PP 74/2014, pengiriman barang menggunakan sepeda motor tidak dilarang namun tetap harus memperhatikan beberapa hal yaitu muatan memiliki lebar tidak melebihi setang kemudi, tinggi muatan tidak

6 Baca Ketentuan Umum Penyelenggaran Grab Express. 
melebihi 900 milimeter dari atas duduk pengemudi, barang muatan ditempatkan di belakang pengemudi.

4. Pertanggungan asuransi pada setiap barang yang dikirimkan

Sebagaimana yang telah ditulis di dalam situs resmi Grab Indonesia, konsumen tidak perlu khawatir barang akan mengalami kerusakan. Pihak Grab Indonesia telah menjamin bahwa pada setiap pengiriman barang menggunakan Grab Express mendapatkan jaminan asuransi hingga sebesar Rp 10.000.000,- (sepuluh juta rupiah). Pemberian jaminan ini adalah sebagai wujud bentuk perlindungan bagi konsumen.

Berbeda dengan penyedia layanan angkutan berbasis aplikasi lainnya yang menjadi pesaing dari Grab Indonesia yaitu Go-Jek. Go-Jek juga memiliki layanan pengiriman paket kilat yang memiliki konsep layaknya Grab Express, bernama Go-Send. Pada layanan ini, pengiriman dilakukan dengan driver gojek. Driver biasa yang telah terdaftar pada PT Go-Jek Indonesia dapat melakukan layanan Gojek dan juga Go-Send. Pada Go-Send, para driver tidak mendapat pelatihan khusus untuk melakukan pengantaran barang yang akan dikirim. Semua driver dianggap sama dan dapat melakukan semua layanan yang ada menggunakan sepeda motor. Untuk pengiriman, pada praktiknya, Go-Send tidak difasilitasi oleh tas kanvas ataupun tali pengait seperti yang berlaku pada Grab Express. Sehingga pada pengiriman barang menggunakan layanan GoSend memiliki risiko terjadinya kerusakan barang lebih besar dibandingkan dengan menggunakan Grab Express.

\section{Pertanggungjawaban Pengangkut dalam Proses Pengiriman Barang Menggunakan}

\section{Layanan Grab Express}

Segala bentuk kegiatan yang dilakukan oleh manusia pastilah memiliki risiko. ${ }^{7}$ Termasuk juga pada pengiriman barang menggunakan Grab Express. Risiko tersebut tidak bisa diketahui dengan pasti waktu terjadinya. Pada penyelenggaraan pengiriman barang Grab Express misalnya, para pihak tidak akan mengetahui bahaya atau risiko yang akan terjadi sehingga memiliki dampak pada pengiriman barang tersebut contohnya barang yang dikirim rusak.

7 Menurut Kamus Besar Bahasa Indonesia, arti dari kata risiko adalah akibat kurang menyenangkan (merugikan, membahayakan) dari suatu tindakan atau perbuatan. 
Pada dasarnya risiko kecelakaan lalu lintas akan selalu ada. meskipun telah dilakukan upaya pencegahan, kekhawatiran terhadap kemungkinan risiko barang rusak akan tetap ada dan tentunya harus diatasi. Grab Indonesia selaku perusahaan penyedia aplikasi dan pengirim sebagai konsumen memiliki hubungan hukum setelah dibuatnya perjanjian pengangkutan barang tersebut. Hubungan hukum yang timbul di antara keduanya dilaksanakan dengan mengacu pada asas-asas umum perlindungan konsumen. Sebagai pelaku usaha penyedia aplikasi layanan Grab Express, sudah seharusnya Grab Indonesia memberikan kepastian hukum bagi pengirim barang selaku konsumen. Grab Indonesia wajib memberikan proteksi pada setiap barang yang dikirimkan menggunakan Grab Express. Proteksi yang diberikan adalah berupa keamanan dan keselamatan pada barang hingga memberikan ganti rugi apabila terjadi suatu kesalahan. Hal ini sejalan dengan adanya amanat pada Undang-Undang No. 8 Tahun 1999 Tentang Perlindungan Konsumen (UUPK).

Pada konsiderans UUPK huruf (d) menyatakan bahwa, "untuk meningkatkan harkat dan martabat konsumen perlu meningkatkan kesadaran, pengetahuan, kepedulian, kemampuan dan kemandirian konsumen untuk melindungi dirinya serta menumbuhkembangkan sikap pelaku usaha yang bertanggungjawab". Menurut ketentuan tersebut, bahwa konsumen harus memiliki kesadaran serta ketelitian dalam penggunaan barang dan/atau jasa. Serta bagi pelaku usaha wajib memiliki sikap yang baik dalam melakukan kegiatan usaha dan bertanggungjawab atas segala kesalahan yang dilakukannya. Dalam hal ini, posisi Grab Indonesia adalah sebagai pelaku usaha dan pengirim barang selaku konsumen.

Pada pemberlakuan UUPK juga mengatur tentang hak dan kewajiban konsumen dan pelaku usaha. Dalam hal ini, pengirim barang merupakan konsumen yang memiliki hak sesuai yang tertera pada Pasal 4 UUPK tentang hak konsumen adalah sebagai berikut:

a. hak atas kenyamanan, keamanan dan keselamatan dalam mengonsumsi barang dan/atau jasa;

b. hak untuk memilih barang dan/atau jasa serta mendapatkan barang dan/atau jasa tersebut sesuai dengan nilai tukar dan kondisi serta jaminan yang dijanjikan;

c. hak atas informasi yang benar, jelas dan jujur mengenai kondisi dan jaminan barang dan/atau jasa; 
d. hak untuk didengar pendapat dan keluhannya atas barang dan/atau jasa yang digunakan;

e. hak untuk mendapatkan advokasi, perlindungan dan upaya penyelesaian sengketa perlindungan konsumen secara patut;

f. hak untuk mendapat pembinaan dan pendidikan konsumen;

g. hak untuk diperlakukan atau dilayani secara benar dan jujur serta tidak diskriminatif;

h. hak untuk mendapatkan kompensasi, ganti rugi dan/atau penggantian, apabila barang dan/atau jasa yang diterima tidak sesuai dengan perjanjian atau tidak sebagaimana mestinya;

i. hak-hak yang diatur dalam ketentuan peraturan perundang-undangan lainnya.

Pada pemberlakuan UUPK juga mengatur tentang kewajiban pelaku usaha. yang dalam hal ini, Grab Indonesia yang merupakan penyedia layanan Grab Express. Grab Express dalam hal ini bertindak sebagai pelaku usaha memiliki kewajiban sesuai yang diamanatkan pada Pasal 7 UUPK. Kewajiban pelaku usaha adalah sebagai berikut:

a. beritikad baik dalam melakukan kegiatan usahanya;

b. memberikan informasi yang benar, jelas dan jujur mengenai kondisi dan jaminan barang dan/atau jasa serta memberi penjelasan penggunaan, perbaikan dan pemeliharaan;

c. memperlakukan atau melayani konsumen secara benar dan jujur serta tidak diskriminatif;

d. menjamin mutu barang dan/atau jasa yang diproduksi dan/atau diperdagangkan berdasarkan ketentuan standar mutu barang dan/atau jasa yang berlaku;

e. memberi kesempatan kepada konsumen untuk menguji dan/atau mencoba barang dan/atau jasa tertentu serta memberi jaminan dan/atau garansi atas barang yang dibuat dan/atau yang diperdagangkan;

f. memberi kompensasi, ganti rugi dan/atau penggantian atas kerugian akibat penggunaan, pemakaian dan pemanfaatan barang dan/atau jasa yang diperdagangkan;

g. memberi kompensasi, ganti rugi dan/atau penggantian apabila barang dan/atau jasa yang diterima atau dimanfaatkan tidak sesuai dengan perjanjian. 
Apabila dikaitkan dengan peraturan di atas, Grab Indonesia wajib melaksanakan dua hal penting. Pertama, dalam hal sebagai pelaku usaha, Grab Indonesia wajib menjamin keselamatan dan keamanan barang yang dikirimkan menggunakan Grab Express. Pengirim selaku konsumen berhak mendapatkan keterangan dan jaminan bahwa jasa angkutan yang dilaksanakan adalah baik dan bermutu sehingga barang yang dikirim akan sampai di tempat tujuan dengan kondisi aman dan selamat. Kedua, selaku pelaku usaha Grab Indonesia wajib memberi ganti rugi atau kompensasi. Jika terjadi kerugian yang diderita oleh pengirim terkait barangnya, pengirim berhak menerima kompensasi ganti rugi dan/atau penggantian dari Grab Indonesia. Penggantian kerugian dilakukan bila barang yang dikirim tidak sesuai dengan yang diperjanjikan ataupun tidak sebagaimana keadaan semua saat barang dikirim.

Sesuai dengan yang telah dijelaskan di atas, dapat dikatakan bahwa secara umum tanggung jawab berada pada pengangkut. Hal ini terlihat dari penyelenggaraan pengangkutan dibuat berdasarkan perjanjian pengangkutan yang telah disepakati para pihak. Lazimnya, pengangkut bertanggung gugat terhadap kerugian yang diderita pengirim barang dan/atau penerima barang, sepanjang kerugian tersebut merupakan akibat dari pelaksanaan penyelenggaraan pengangkutan. Sejalan dengan yang telah diamanatkan dalam UUPK, pada Undang-Undang No. 22 Tahun 2009 Tentang Lalu Lintas dan Angkutan Jalan Raya (UULLAJ) pun juga mengatur tentang kewajiban pengangkut untuk bertanggung jawab. Hal ini tertulis pada Pasal 188 UULLAJ yang menyebutkan, "Perusahaan angkutan umum wajib mengganti kerugian yang diderita oleh penumpang atau pengirim barang karena lalai dalam melaksanakan pelayanan angkutan".

Selain itu pada Pasal 189 UULLAJ menyatakan bahwa, "perusahaan angkutan umum wajib mengasuransikan tanggungjawabnya sebagaimana dimaksud dalam Pasal 188". Meskipun bukan merupakan perusahaan angkutan umum, posisi Grab Indonesia dianggap sama sebab perusahaan ini sebagai penyedia aplikasi layanan jasa transportasi sehingga wajib memberi ganti rugi. Ganti kerugian yang diberikan adalah dengan memberikan asuransi. Terdapat pembatasan terkait dengan pertanggung jawaban pengangkut yang diatur dalam Pasal 193 ayat (1) UULLAJ. Pada pasal ini mengatakan bahwa:

"Perusahaan angkutan umum bertanggung jawab atas kerugian yang diderita oleh pengirim barang karena barang musnah, hilang, atau rusak akibat penyelenggaraan angkutan, kecuali terbukti bahwa musnah, hilang, atau rusaknya barang disebabkan oleh suatu kejadian yang tidak dapat dicegah atau dihindari atau kesalahan pengiriman". 
Dapat dipahami bahwa pengangkut bertanggungjawab atas kerugian yang diderita pengirim selama dapat dibuktikan bahwa kerugian tersebut akibat perbuatan pengangkut. Pada ayat lanjutannya, Pasal 193 ayat (3) UULLAJ, menyatakan bahwa, "tanggung jawab sebagaimana dimaksud pada ayat (1) dimulai sejak barang diangkut sampai barang diserahkan di tempat tujuan yang disepakati". Pernyataan ayat tersebut menegaskan bahwa pembatasan pertanggung jawaban hanya saat barang mulai diangkut hingga diterima di tempat tujuan. Apabila kerusakan terjadi di luar batasan tersebut, maka itu bukan menjadi tanggung jawab pengangkut.

Berdasarkan hal ini, sejatinya yang menjadi fokus utama adalah adanya risiko yang tidak pasti dalam penyelenggaraan pengiriman barang tersebut. Risiko yang dapat terjadi seperti barang tersebut hilang dan/atau rusak. Untuk itu, diperlukan lembaga yang mampu menanggung sebagian dari risiko yang mungkin dialami oleh setiap orang. ${ }^{8}$ Pada hal ini lembaga yang cocok dan diperlukan adalah asuransi.

Adanya berbagai faktor yang memicu terjadinya permasalahan pada pengiriman barang, membuat Grab Indonesia wajib memberikan sebuah perlindungan kepada para konsumennya yakni pengirim barang. Sesuai dengan amanat Pasal 188 dan Pasal 189 UULLAJ, maka perlindungan yang diberikan Grab Indonesia kepada konsumen Grab Express adalah memberikan asuransi terhadap barang yang dikirimkan. Dilansir pada website resmi Grab Indonesia pada penjelasan layanan Grab Express, menyatakan bahwa seluruh pengiriman paket melalui Grab Express diasuransikan hingga Rp 10.000.000. Kelebihan yang dimiliki oleh Grab Indonesia adalah dalam setiap pengiriman paket dengan menggunakan Grab Express pengirim tidak perlu menambah biaya penjaminan asuransi. Biasanya pada ekspedisi konvensional, pengirim paket yang ingin menggunakan layanan asuransi sebagai proteksi terhadap barang diwajibkan untuk membayar biaya tambahan di luar biaya pengiriman yang disebut premi asuransi.

Prinsip asuransi sebagaimana yang telah diatur dalam Pasal 246 KUHD yaitu, "asuransi atau pertanggungan adalah suatu perjanjian dengan mana seseorang penanggung mengikatkan diri kepada seseorang tertanggung dengan menerima suatu premi untuk memberikan penggantian kepadanya karena suatu kerugian, kerusakan atau kehilangan keuntungan yang diharapkan, yang mungkin akan dideritanya karena suatu peristiwa yang tak tentu". Kemudian pengaturan yang lebih luas lagi telah diatur dalam

8 Hilda Yunita Sabrie dan Rizky Amalia, 'Karakteristik Hubungan Hukum Dalam Asuransi Jasaraharja Terhadap Klaim Korban Kecelakaan Angkutan Umum', Yuridika, Vol. 30, No. 3, 2015, hlm. 389. 
Undang-Undang Nomor 40 Tahun 2014 tentang Perasuransian (selanjutnya disebut UU Perasuransian) pada Pasal 1 angka (1) menyatakan bahwa:

Asuransi adalah perjanjian antara dua pihak, yaitu perusahaan asuransi dan pemegang polis, yang menjadi dasar bagi penerimaan premi oleh perusahaan asuransi sebagai imbalan untuk:

a. memberikan penggantian kepada tertanggung atau pemegang polis karena kerugian, kerusakan, biaya yang timbul, kehilangan keuntungan, atau tanggung jawab hukum kepada pihak ketiga yang mungkin diderita tertanggung atau pemegang polis karena terjadinya suatu peristiwa yang tidak pasti; atau

b. memberikan pembayaran yang didasarkan pada meninggalnya tertanggung atau pembayaran yang didasarkan pada hidupnya tertanggung dengan manfaat yang besarnya telah ditetapkan dan/atau didasarkan pada hasil pengelolaan dana.

Melihat uraian definisi di atas, dapat disimpulkan bahwa tujuan utama dari diadakannya suatu asuransi adalah untuk mengalihkan risiko dari tertanggung yang mempunyai kepentingan terhadap objek asuransi kepada penanggung yang timbul sebagai akibat adanya ancaman bahaya risiko.

Pada setiap dilaksanakannya penutupan asuransi pasti terdapat perjanjian asuransi. Perjanjian asuransi ini dibuat oleh para pihak yakni penanggung dan tertanggung. Penanggung adalah pihak yang mengambil alih risiko pihak lain dengan memberikan kompensasi ataupun ganti rugi kepada tertanggung atau si penderita kerugian. Sedangkan tertanggung adalah pihak yang berhak mendapat kompensasi akibat adanya kerugian yang diderita dan ganti rugi tersebut diberikan oleh si penanggung. Bila dikaitkan dengan penyelenggaraan pengiriman barang menggunakan Grab Express, asuransi yang diberikan juga harus memperhatikan prinsip-prinsip dalam hukum asuransi. Prinsip yang berlaku pada hukum asuransi adalah sebagai berikut:

\section{Prinsip Kepentingan yang Dapat Diasuransikan}

Hukum asuransi menentukan bahwa apabila seseorang menutup perjanjian asuransi, maka yang bersangkutan harus memiliki kepentingan terhadap objek yang diasuransikannya. Prinsip ini banyak dikenal dengan sebutan prinsip insurable interest. ${ }^{9}$ Mengenai prinsip ini diatur dalam Pasal 250 KUHD yang berbunyi:

9 Insurable interest is a direct monetary interest in the insured property sufficient to result in monetary loss should the property be damaged and destroyed. Dalam bahasa Indonesia memiliki arti "Kepentingan yang dapat diasuransikan adalah kepentingan langsung atas harta yang diasuransikan yang cukup untuk menghasilkan kerugian jika harta benda tersebut rusak dan hancur. Dikutip dari http://www.allenins.com/Inscurance Definitions.html, diakses pada tanggal 27 November 2017. 
"Apabila seseorang yang telah mengadakan sesuatu perjanjian asuransi untuk diri sendiri, atau apabila seorang yang untuknya telah diadakan suatu asuransi, pada saat diadakannya asuransi itu tidak mempunyai suatu kepentingan terhadap barang yang diasuransikan itu, maka penanggung tidak diwajibkan memberi ganti kerugian".

Jelas dari ketentuan tersebut, bahwa kepentingan merupakan syarat yang mutlak untuk dapat diadakannya perjanjian asuransi. Bila hal itu tidak dipenuhi maka penanggung tidak diwajibkan untuk memberikan ganti rugi. ${ }^{10}$ Pada kasus ini, Grab Indonesia selaku pelaku usaha telah menjamin adanya asuransi untuk setiap barang yang dikirimkan menggunakan layanan Grab Express. Grab Indonesia memiliki kepentingan di dalamnya yakni sebagai ekspeditor yang berkewajiban untuk menjamin keselamatan barang. Sehingga apabila Grab Indonesia memberikan asuransi kepada setiap barang yang diangkut adalah tindakan yang benar dan tidak dilarang oleh peraturan perundangundangan.

\section{Prinsip Itikad Baik}

Pada penutupan perjanjian asuransi juga terdapat prinsip itikad baik atau dalam bahasa inggris sering disebut utmost good faith. Sesuai dengan Pasal 1338 BW, sebuah persetujuan atau perjanjian harus dilaksanakan dengan itikad baik. Prinsip itikad baik ini juga merupakan manifestasi dari syarat sahnya perjanjian yang diatur di dalam Pasal 1320 ayat (1) BW yaitu adanya kata sepakat. ${ }^{11}$ Prinsip ini dapat diartikan bahwa masing-masing pihak wajib untuk memberi keterangan dan informasi selengkap-lengkapnya. Prinsip itikad baik ini dapat lebih jelas dilihat pada Pasal 251 KUHD yang terkait dengan kewajiban untuk memberikan keterangan yang sebenarnya. ${ }^{12}$ Pada pemberlakuan asuransi sebagai wujud ganti rugi Grab Express, pengirim wajib memberikan keterangan yang jelas dan terbuka pada Grab Indonesia. Begitu pun sebaliknya, Grab Indonesia juga wajib memberi keterangan terkait barang apa saja yang dapat dikover menggunakan asuransi ganti rugi dari Grab Indonesia dan juga besaran jumlah ganti rugi.

10 Mulhadi, Dasar-Dasar Hukum Asuransi, Jakarta: Rajawali Pers, 2017, hlm. 81.

11 Hilda Yunita Sabrie dan Rizky Amalia. Op.Cit., hlm. 394.

12 Pasal 252 KUHD yaitu "kecuali dalam hal-hal yang disebutkan dalam ketentuan undang-undang, maka tidak bolehlah diadakan suatu pertanggungan kedua, untuk jangka waktu yang sudah dipertanggungkankah untuk harganya penuh, dan demikian itu atas ancaman batalnya pertanggungan kedua tersebut." Pasal ini menjelaskan bahwa tertanggung tidak diperbolehkan untuk mendapatkan keuntungan dari penanggung atas kerugian yang ia derita kecuali ditentukan lain oleh undang-undang." 
Bila dilihat dari website resmi Grab Indonesia, pada penjelasan Grab Express mencantumkan terkait kemungkinan terjadinya kerusakan dan cara untuk mengajukan klaimnya. Grab Indonesia juga menjelaskan bahwa terdapat beberapa jenis barang yang tidak dapat diasuransikan seperti kertas dan dokumen, voucher, kupon, giro, cek, barang pecah belah, cairan dan bahan kimia, senjata, makanan, minuman, buah dan sayuran segar, karangan bunga, barang mudah terbakar, alkohol dan obat terlarang, binatang hidup, uang, barang paket yang melebihi ukuran yang direkomendasikan oleh Grab Indonesia serta paket lain yang dilarang oleh undang-undang. ${ }^{13}$ Dengan demikian apabila terdapat barang yang mengalami kerusakan pada saat dikirimnya barang menggunakan Grab Express namun paket tersebut adalah salah satu barang yang dilarang atau tidak dapat diasuransikan sesuai peraturan pada Grab Express, maka proses permintaan klaim ganti rugi tidak dapat dilaksanakan.

\section{Prinsip Ganti Kerugian}

Prinsip asuransi selanjutnya ada prinsip ganti kerugian. Pada hakikatnya fungsi asuransi adalah mengalihkan atau membagi risiko atau kemungkinan yang diderita atau dihadapi oleh tertanggung karena terjadi suatu peristiwa tidak pasti. Oleh karena itu, besarnya ganti kerugian yang diterima oleh tertanggung harus seimbang dengan kerugian yang dideritanya. Hal ini merupakan inti dari prinsip ganti kerugian (indemnity principle) atau disebut juga prinsip keseimbangan. ${ }^{14}$ Prinsip ini tercermin dalam Pasal 246 KUHD, yaitu pada bagian kalimat “...untuk memberikan pergantian kepadanya karena suatu kerugian, kerusakan, atau kehilangan keuntungan yang diharapkan yang mungkin akan dideritanya karena suatu peristiwa yang tidak pasti".

Grab Indonesia akan mengganti kerugian tidak lebih dari kerugian yang diderita oleh pengirim. Menurut Mulhadi Sarjana Hukum, batas tertinggi kewajiban penanggung adalah memulihkan tertanggung pada posisi ekonomi yang sama dengan posisi semula sebelum terjadinya kerugian. ${ }^{15}$ Jika tertanggung mendapatkan keuntungan atas terjadinya suatu kerugian, maka akan banyak orang yang tergoda untuk sengaja menimbulkan kerugian demi mendapatkan keuntungan tersebut. ${ }^{16}$ Untuk pemberian ganti rugi, Grab

13 Grab Indonesia, 'Layanan Grab Express', Grab Indonesia, https://www.grab.com/id/express/, diakses pada tanggal 27 November 2017.

14 Mulhadi, Op.Cit., hlm. 85.

15 Ibid, hlm. 86.

16 A. Hasymi Ali, Pengantar Asuransi, Jakarta: Bumi Aksara, 1995, hlm. 183. 
Indonesia batasan tertinggi adalah mengganti rugi seluruh kerugian yang dialami oleh pengirim. Demi mendapatkan keseimbangan antara kerugian yang diderita dan pemberian ganti rugi harus diketahui nilai dan harga dari objek yang dikirimkan sebagai objek yang diasuransikan.

\section{Prinsip Subrogasi}

Dalam perjanjian asuransi, terdapat kemungkinan peristiwa kerugian terjadi disebabkan oleh pihak ketiga. Dalam keadaan biasa, kerugian yang ditimbulkan oleh pihak ketiga tersebut mengakibatkan harus dipertanggungjawabkan oleh pelakunya. Dengan kata lain pemilik barang dapat melakukan tuntutan kepada pihak ketiga untuk memberikan ganti kerugian atas perbuatannya. ${ }^{17}$ Apabila tertanggung telah mendapat ganti rugi dari penanggung, namun ia juga meminta ganti kerugian atas perbuatan yang dilakukan pihak ketiga, maka hal ini dapat membuat tertanggung mendapatkan ganti rugi melebihi kerugiannya. Jika hal ini terjadi maka sangat bertolak belakang dengan prinsip ganti kerugian sebagaimana yang telah dijelaskan sebelumnya.

Untuk menghindari hal ini, KUHD telah mengatur mengenai hal tersebut dalam Pasal 284 KUHD yang berbunyi:

"Penanggung yang telah membayar kerugian barang yang dipertanggungkan, memperoleh semua hak yang sekiranya dimiliki oleh tertanggung terhadap pihak ketiga berkenaan dengan kerugian itu; dan tertanggung bertanggung jawab untuk setiap perbuatan yang mungkin merugikan hak penanggung terhadap pihak ketiga itu".

Prinsip subrogasi ini timbul semata-mata untuk tujuan menegakkan prinsip indemnitas, mencegah tertanggung mendapatkan keuntungan dari ganti kerugian yang telah diberikan pihak ketiga sebagai akibat dari bentuk kerugian. Dengan demikian, dapat disimpulkan bahwa tujuan prinsip subrogasi dalam perjanjian asuransi adalah untuk mencegah timbulnya ganti kerugian ganda kepada tertanggung dan mencegah pihak ketiga terbebas dari kewajibannya sebagai bentuk pertanggungjawaban atas perbuatannya. 18

Adanya asuransi pada Grab Indonesia memberikan perlindungan bagi pengirim barang menggunakan layanan Grab Express. Pemberian asuransi bagi pengirim barang ini

17 Mulhadi, Loc.Cit., hlm. 86.

18 Heru Susanto, 'Subrogasi Sebagai Bentuk Pertanggungjawaban Pihak Ketiga Terhadap Penanggung Dalam Perasuransian', Masalah-Masalah Hukum, Vol. 35, No. 4, Oktober-Desember 2006, hlm. 397. 
berupa asuransi kerugian. Asuransi kerugian adalah suatu perjanjian asuransi yang berisikan ketentuan bahwa penanggung mengikatkan dirinya untuk melakukan prestasi berupa pemberian ganti kerugian kepada tertanggung seimbang dengan kerugian yang diderita oleh pihak tertanggung. ${ }^{19}$

Pada laman resmi Grab Indonesia terkait Grab Express telah menerangkan bahwa seluruh pengiriman paket menggunakan Grab Express terasuransikan hingga Rp 10.000.000 (sepuluh juta rupiah). Grab Indonesia juga telah mengatur barang yang dapat dikirimkan menggunakan Grab Express sejatinya adalah barang apa saja selama sesuai barang yang dikirim sesuai dengan batas maksimal muatan barang seperti yang telah diatur dan dijelaskan pada bab sebelumnya. Misalnya barang-barang yang dapat dikirim adalah dokumen penting, pakaian, jas hujan yang tertinggal, makanan dan minuman yang dikemas dengan baik, barang elektronik kering, parsel, paket ukuran sedang, alat rumah tangga, buku dan peralatan alat tulis, tas, handphone, barang kiriman atau barang belanjaan, sepatu dan sandal, buah dan sayur segar, perhiasan, kupon, voucher dan masih banyak lagi.

Untuk barang-barang seperti handphone, alat elektronik, paket pecah belah, serta makanan basah yang tidak dibungkus dengan baik harus dikirim dengan perhatian khusus dan lebih hati-hati. Barang-barang tersebut dapat diantar, namun driver wajib mengkomunikasikan kepada pengirim bahwa terdapat risiko yang dapat saja timbul jika barang-barang tersebut dikirim menggunakan sepeda motor. Jika pengirim setuju dan barang telah terbungkus dengan baik, rapi dan kedap air maka pengangkutan dapat dilaksanakan.

Dari sekian banyak jenis barang yang dapat dikirimkan, tidak semua barang dapat dilindungi oleh asuransi. Barang-barang yang tidak dilindungi oleh asuransi pada Grab Express antara lain seperti kertas dan dokumen, voucher, kupon, giro, cek, barang pecah belah, cairan dan bahan kimia, senjata, makanan, minuman, buah dan sayuran segar, karangan bunga, barang mudah terbakar, alkohol dan obat terlarang, binatang hidup, uang, barang paket yang melebihi ukuran yang direkomendasikan oleh Grab Indonesia serta paket lain yang dilarang oleh undang-undang. Hal ini ditulis pada pedoman Grab Express di laman resmi Grab Indonesia pada layanan Grab Express. Di luar hal yang tidak

${ }^{19}$ Mulhadi, Op.Cit., hlm. 93. 
diasuransikan sesuai yang telah dicantumkan, maka barang tersebut dapat perlindungan asuransi.

Apabila selama pengiriman dan setelah diterimanya barang tersebut terbukti terjadi kerusakan, maka pengirim dapat melaporkan ke customer service dengan mengirimkan email ke pihak Grab Indonesia. Pengirim di wajibkan untuk mencantumkan nomor pesanan serta nomor telepon pengirim yang dapat dihubungi. Untuk proses pengajuan asuransi, pengirim wajib melaporkan maksimal paling lama 3 x 24 jam terhitung dari proses booking pesanan Grab Express. Berbeda dengan asuransi kecelakaan yang di berikan kepada penumpang Grab Bike, pada Grab Express tidak memiliki form khusus untuk pengaduan. Pada Grab Bike, bila penumpang mengalami kecelakaan dapat melapor dan meminta ganti rugi kepada Grab Indonesia dengan mengisi form pengaduan yang di dalamnya memuat nama lengkap penumpang, nomor telepon, email, tanggal dan jam terjadi kecelakaan, lokasi jemput dan tujuan, deskripsi cedera yang diderita dan menyertakan foto sebagai tanda bukti telah terjadi kecelakaan pada penumpang.

Berkaca pada form yang disediakan oleh Grab Indonesia untuk pengaduan kecelakaan menggunakan Grab Bike, maka untuk pengaduan kerusakan barang menggunakan Grab Express, pengirim dapat juga melakukan hal yang sama. Pengirim yang mengalami kerusakan barang dapat mengirimkan email ke pihak Grab dengan mencantumkan nama pengirim, nomor pemesanan Grab Express, nomor telepon, tanggal dan jam pemesanan, lokasi pengambilan barang dan lokasi tujuan barang, jenis dan jumlah barang yang dikirimkan, kerugian yang diderita serta foto kerusakan barang itu sendiri. Keterangan ini lalu dikirimkan melalui surat elektronik ke pihak Grab Indonesia. Proses penggantian kerugian atas barang yang rusak membutuhkan waktu maksimal 30 hari sejak diterimanya laporan kerusakan barang dari pengirim.

Besar ganti kerugian yang diberikan tergantung pada jenis barang. Pihak Grab Indonesia akan menilai harga barang tersebut yang disamaratakan dengan standar harga barang di pasaran pada saat diterimanya klaim. Lazimnya pada pengiriman barang, penggantian atas kerugian yang diderita adalah 10 kali dari biaya angkut atau biaya kirim yang telah di bayarkan atau besarnya ganti rugi setara dengan harga barang tersebut. Prinsip ganti rugi adalah mengganti sebagian atau lebih kerusakan yang diderita seseorang dan tidak memberikan penggantian melebihi dari harga barang itu sendiri.

Contohnya adalah pada pengiriman barang menggunakan Grab Express, pengirim mengirimkan paket elektronik berupa keyboard komputer sejumlah 1 dengan merek 
"ASUS". Pengiriman tersebut berbiaya sebesar Rp 25.000 (dua pulih lima ribu rupiah). Saat pengiriman dilaksanakan, keyboard komputer tersebut dalam kondisi baik dan tidak memiliki suatu cacat apa pun serta telah dibungkus dengan baik dan rapi. Setibanya di tujuan ternyata keyboard komputer tersebut rusak, kabelnya terlepas. Rusaknya keyboard komputer bisa dilatar belakangi oleh berbagai faktor seperti yang telah dibahas sebelumnya. Pengirim dapat melaporkan kerugian yang diderita kepada pihak Grab Indonesia dengan mencantumkan keterangan lengkap beserta dokumen pengiriman dan jenis muatannya. Barulah Grab Indonesia akan melakukan ganti kerugian. Pihak Grab Indonesia akan menilai kerusakan yang diderita.

Biasanya Grab akan memberikan ganti rugi maksimal 10 kali dari biaya pengiriman. Sehingga maksimal ganti rugi adalah $\mathrm{Rp} 250.000$ (dua ratus lima puluh ribu rupiah). Apabila kerugian yang diderita pengirim dalam kondisi hampir 100\% maka pihak Grab akan memberikan ganti rugi sebesar harga keyboard komputer tersebut. Grab akan melakukan penilaian terhadap harga standar keyboard komputer "ASUS" pada saat itu dan menggantinya sesuai dengan harga yang setara dengan barang tersebut selama tidak melebihi asuransi yang disediakan oleh Grab Indonesia yakni Rp 10.000 .000 (sepuluh juta rupiah). Jika ternyata harga keyboard komputer tersebut lebih dari sepuluh juta rupiah maka penggantian kompensasi hanya sebesar sepuluh juta rupiah saja. Hal ini berlaku pada proses klaim asuransi bagi pengirim selaku konsumen dari layanan Grab Express.

\section{KESIMPULAN}

Pengiriman barang menggunakan moda transportasi sepeda motor dalam layanan Grab Express, merupakan suatu bentuk kepekaan pengusaha untuk menangkap peluang bisnis dalam dunia pengangkutan terutama pengangkutan barang. Barang yang dapat dikirimkan menggunakan layanan Grab Express pun terbatas, hanya meliputi barang umum yang tidak membutuhkan alat pengangkutan khusus. Pengemasan dalam Grab Express juga menjadi unsur penting untuk meminimalisasi kemungkinan risiko seperti terjadinya kerusakan barang. Apabila barang rusak pada saat dilakukan pengiriman, Grab Indonesia juga telah menyediakan perlindungan bagi konsumennya berupa asuransi di setiap pengiriman barangnya maksimal sebesar Rp 10.000.000 (sepuluh juta rupiah).

Pemberian asuransi pada Grab Express adalah langkah yang sangat tepat. Namun akan lebih baik jika Grab Indonesia bekerja sama dengan suatu perusahaan asuransi untuk penggantian bila terjadi kerugian pada konsumen. Nantinya apabila bekerja sama dengan 
perusahaan asuransi, Grab Indonesia juga wajib memberikan info yang lebih jelas kepada konsumen terkait perusahaan asuransi apa yang turut menanggung bila terjadi kerugian pada proses pengiriman barang. Tak hanya itu, Grab Indonesia melalui laman resminya juga harus memberikan transparansi terkait besar nominal dan jumlah penggantian ganti rugi kepada konsumennya.

\section{Daftar Pustaka}

\section{Buku}

Ali, A. Hasymi, Pengantar Asuransi, Jakarta: Bumi Aksara, 1995

Marzuki, Peter Mahmud, Penelitian Hukum, Jakarta: Kencana Prenadamedia Group, 2005

Mulhadi, Dasar Dasar Hukum Asuransi, Jakarta: Rajawali Pers, 2017

\section{Jurnal}

Susanto, Heru, 'Subrogasi Sebagai Bentuk Pertanggungjawaban Pihak Ketiga Terhadap Penanggung Dalam Perasuransian', Masalah-Masalah Hukum, Vol. 35, No. 4, OktoberDesember 2006.

Sabrie, Hilda Yunita dan Rizky Amalia, 'Karakteristik Hubungan Hukum Dalam Asuransi Jasaraharja Terhadap Klaim Korban Kecelakaan Angkutan Umum', Yuridika, Vol. 30, No. 3, 2015.

\section{Internet}

Novita, 'Profil Singkat Grab', Grab Indonesia, http://nitanovitasr.blogspot.co.id/2016/10/profil-singkat-grab.html, diakses pada tanggal 25 Oktober 2017.

Grab Indonesia, 'Layanan', Grab Indonesia, http://www.grab.com/id/ diakses pada tanggal 25 Oktober 2017.

Allen Insurance Group, 'Insurance Definition', Allen Insurance Group, http://www.allenins.com/Inscurance Definitions.html, diakses pada tanggal 27 November 2017.

Grab Indonesia, 'Layanan Grab Express', Grab Indonesia, https://www.grab.com/id/express/, diakses pada tanggal 27 November 2017. 